\title{
Anlık Duygu Durumu ve Mutluluğun Plansız Satın Almaya Etkisi
}

\author{
DOI: 10.26466/opus.536345
}

\author{
İbrahim Yemez ${ }^{*}$ Şükran Karaca** \\ * Dr,Arş. Gör. Sivas Cumhuriyet Üniversitesi, İ̈BF,Merkez / Sivas / Türkiye \\ E-Posta: ibrahimyemez@cumhuriyet.edu.tr \\ ORCID: $0000-0003-3176-6394$ \\ ** Dr. Öğr. Üyesi, Sivas Cumhuriyet Üniversitesi, Turizm Fakültesi/Merkez / Sivas / Türkiye \\ E-Posta: sukrankaraca@gmail.com \\ ORCID: $\underline{0000-0002-0268-1810}$
}

Öz

Duygu, genel olarak bireyin nasıl hissettiği ve hissettiği şeyin bireyde ne tür bir etki yarattı̆̆ına odaklanmaktadır. Mutluluk ise, bireyin yaşamına dair olumlu düşünce ve duygularının miktarca üstünlüğ̈̈ yani bireylerin yaşamlarından aldıkları doyum ve olumlu duyguların toplamıdır. Bu bağlamda bu çalışmanın amacını anlık duygu durumu ve mutluluk değişkenlerinin plansız satın alma davranışı üzerindeki etkisini incelemek oluşturmaktadır. Bu amaçla Sivas ilinde kolayda örnekleme metoduyla belirlenen 399 kişi ile yüz yüze anket tekniği ile veriler toplanmıştır. "Anlık Duygu Durumu", "Mutluluk" ve "Plansız Satın Alma" değiş̧kenlerinin katıllmciların yaş, cinsiyet, medeni durum, eğitim seviyesi ve meslek türlerine göre karşılaştırılmasında Bağımsız Örneklemler T Testi, Tek Yönlü Varyans Analizi kullanılmıştır. Daha sonra anlık duygu durumu ve mutluluğun plansız satın alma davranışı üzerinde etkisinin olup olmadığ doğrusal regresyon analizi ile incelenmiştir. Analiz sonuçlarına göre anlık duygu durumu ve mutluluk değişkenlerinin plansız satın alma davranışıyla orta/pozitif düzeyde ve anlamlı bir ilişki içinde oldukları tespit edilmiştir. Ayrıca anlık duygu durumu ve mutluluk değişkenlerinin plansız satın alma davranışııı \%17 oranında açıklamaktadır.

Anahtar Kelimeler: Anlık Duygu Durumu, Mutluluk, Plansız Satın Alma 


\title{
Instant Emotion Status and the Effect of Happiness on Unplanned Purchase
}

\begin{abstract}
Emotion focuses on how the individual feels and what he / she feels in general. Happiness is the sum total of positive thoughts and emotions of an individual's life, that is, the sum of satisfaction and positive emotions that individuals receive from their lives. In this context, the purpose of this study is to examine the effect of momentary mood and happiness variables on unplanned purchasing behavior. For this purpose, data were collected by face-to-face survey technique with 399 people who were determined by convenience sampling method in Sivas. Independent samples T-test, one-way analysis of variance in comparison of "Instant Emotion Status", "Happiness" and "Unplanned Purchase" variables according to age, gender, marital status, education level and occupation types of participants used. The Pearson correlation coefficient and multiple linear regression analysis were then investigated for the effect of instant emotion status and happiness on unplanned purchasing behavior. According to the results of the analysis, instant emotion status and happiness variables had a moderate / positive relationship with unplanned buying behavior. It also explains the unplanned buying behavior of instant emotion status and happiness variables by $17 \%$.
\end{abstract}

Keywords: Instant Emotion Status, Happiness, Unplanned Purchase 


\section{Giriş}

Günümüzde satın alımlar tüketicilerin duygusal bileşenlerine göre yapılmaktadır (Filser, 1996, s.90; Lichtle ve Plichon, 2005, s.34). Duygular, kişilere, nesnelere veya olaylara karşı tecrübelerle kazanılan ve bireyi davranışta bulunmaya hazır hale getiren hislerdir (Doğan ve Özdevecioğlu, 2009, s.165). Duygu, genel olarak bireyin nasıl hissettiği ve hissettiği şeyin bireyde ne tür bir etki yarattığına odaklanmaktadır. Bu yönüyle "duygu" kavramı pozitif ve negatif olarak ele alınırken bireyi ne yönde etkilediği kilit bir önem taşımaktadır. Pozitif duygu, bireyde yoğun bir memnuniyet ve negatif duygu ise yoğun bir memnuniyetsizlik eğilimi olarak ifade edilmektedir (Cropanzano vd., 2003, s.832). Pozitif duygu bir bakıma düşünme biçimini değiştirmeye yardımcı olmakta ve düşünceleri esnekleştirerek daha eğlenceli ve daha stratejik düşünmeye yardım etmektedir (Fernandez-Abascal ve Diaz, 2013, s.214). Mutluluk ise, bireyin yaşamına dair olumlu düşünce ve duygularının miktarca üstünlüğü yani bireylerin yaşamlarından aldıkları doyum ve olumlu duyguların toplamıdır (Wilson, 1967, s.295). Başka bir ifadeyle mutluluk, bireyin olumlu duyguları sık, olumsuz duyguları az yaşaması ve yaşamdan yüksek doyum alması olarak ifade edilebilir (Argyle vd., 1989, s.189). Bu tanıma göre mutluluk, bireyin yaşamına ilişkin bilişsel ve duyuşsal değerlendirmelerinin bir sonucudur. Tanımda belirtilen olumlu ve olumsuz duyguların yaşanma sıklığı mutluluğun duyuşsal boyutunu oluştururken, yaşama ilişkin değerlendirmeler ise bilişsel boyutunu oluşturmaktadır (Doğan ve Sapmaz, 2012, s.298).

İnsanlar istediklerini satın aldıklarında mutlu olacaktır ve bu satın alımlar planlı veya plansız gerçekleşebilir. Genel olarak, eğer bir kişi planladığı bir şeyi alırsa bu sıradan bir durum olacaktır. Ancak daha önce planlanmamış bir satın alma yaparsa bu olağandışı bir durum olacak ve bireyi gerçekten mutlu edecektir. Plansız satın alma davranışında iki önemli unsur vardır. İlki yapılan satın alma davranışının daha önceden planlanmamasıdır, yani satın alma davranışının düşünmeden ve farklı nedenleri değerlendirmeden yapılmasıdır. Diğeri ise duygusal yanıtlardır. Duygusal tepkiler satın alma davranışından önce, davranışla beraber eş zamanlı olarak ya da satın alma davranışından sonra ortaya çıkar (Verplanken ve Herabadi, 2001, s.71). Plansız 
satın alma davranışına eşlik eden en belirgin duygular keyif ve heyecandır fakat duygular kendini göstermeden önce bireyde ani bir satın alma dürtüsü davranışın sergilenmesinden önce ortaya çıkar. Zorunlu satın alma davranışının hafifletilmiş bir biçimi olarak da ifade edilebilen plansız satın alma davranışında pişmanlık davranıştan hemen sonra ortaya çıar (Dittmar ve Drury, 2000). Aynı zamanda, plansız satın alma, insanlara mutluluk hissi verebilir. Bir kişi, satın alma işlemini yaptıktan sonra mutlu hissedebilir. Başka bir deyişle, bir satın alma işlemini plansız olarak yaptıktan sonra ortaya çıkan hisler mutluluk, zevk, heyecan ve neşedir. Bu durum normaldir, çünkü karar duygusal olarak düşük kontrol ile verilir. Kısacası, karar bilişsel olarak değil, duygusal olarak yapılır (Handayani vd., 2018, s.285). Olumlu bir ruh haline dayanan plansız satın alma mutluluk hissi sağlayacaktır (Gardner ve Rook, 1988, s.130). Diğer yandan, olumsuz bir ruh hali üzerine kurulu ise pişmanlığa neden olur (Saleh, 2012, s.109). Mutluluk, genel bir memnuniyet perspektifidir. Duyguların etkisini dikkate almak plansız satın alma davranışını daha iyi anlamaya yardımcı olmaktadır (Bessouh ve Belkhir, 2018, s.1). Sonuç olarak, insanların hem duygu durumlarının hem de mutluluklarının plansız satın alma davranışı ile ilişkili olduğu varsayımı bu çalışmanın çıkış noktasını oluşturmaktadır. Bu bağlamda bu araştırma ile anlık duygu durumu ve mutluluğun plansız satın almaya etkisinin incelenmesi amaçlanmıştır. Bu amaç doğrultusunda ilk olarak konu ile ilgili literatür incelenmiş, ikinci kısımda araştırmanın yöntem, model ve hipotezleri hakkında bilgi verilmiş son kısımda ise bulgular ve sonuçlara yer verilmiştir.

\section{Literatür Taraması}

Literatür incelendiğinde doğrudan anlık duygu durumu ve mutluluğun plansız satın alma davranışı üzerinde etkisini ölçen bir çalışmaya rastlanmamıştır. Ancak duygular ve mutluluğun ayrı ayrı ele alındığı ve plansız satın alma davranışı üzerinde etkisinin olduğunu gösteren çalışmalar yerli ve yabancı literatürde mevcuttur. Ruh halinin plansız satın alımını tetiklemede temel rolü vardır. Pozitif ruh hali, bireylerin kendilerini şımartacak bir şey satın almaları için güçlü bir şekilde plansız satın alma davranışına yönlendirmektedir. Bu durum kesinlikle tüketi- 
ciler arasında çok güçlü duygusal tepkiler yaratacak ve geliştirecektir. Öte yandan, olumsuz ruh hali bireylerin kendilerini rahatlatmak ve kendilerini neşelendirmek için dürtüsel bir alım yapmasına neden olabilir (Bessouh ve Belkhir, 2018, s.1).

Rook (1987, s.189) ve Rook ve Hoch (1985, s.23), satın alma işlemine eşlik edebilecek duygusal ve bilişsel reaksiyonlara odaklanan plansız satın alma çalışmaları yapmışlardır. Plansız satın almanın duygusal unsurlarına sahip olduğu anlayışını ifade eden bu çalışmalarda, duygu boyutu içindeki şu özellikler tanımlanmıştır: (1) satın alma için ani ve zorunlu bir istek, (2) çaresizlik hissi, (3) iyi veya kötü hissetme, (4) satın alma ruh halleri ve (5) suçlu hissetme. Başlangıçta 52 ifadeden oluşan bir havuz derlenmiştir. Bu 52 ifadenin Rook (1987) ve Rook ve Hoch (1985) tarafından tanımlanan boyutlara değinmesi amaçlanmıştır. Özellikle 29 ifade deneyimsel bir satın alımın duygusal boyutuna değinmiştir. İfadelerden biri katılımcının satın alma sırasında herhangi bir duygu hissedip hissetmediğine, 7 ifade satın alma arzusunun gücüne ve aciliyetine, 4 ifade çaresizlik hissine, 8 ifade iyi veya kötü hissetme odaklı, 3 ifade suçluluk duygusu ve 6 ifade de ruh halinin yol açtığı alımlara atıfta bulunmaktadir (Piron, 1993, s.342).

Yapılan araştırmalarda tüketicilerin alışveriş sırasında sadece rasyonel davranan bireyler olmadığı ve kişinin duygusal yapısının da satın alma karar sürecini büyük ölçüde etkilediği gösterilmektedir. O'Shaughnessy ve Jackson O'Shaughnessy (2012, s.78-79), duyguların satın alma davranışlarına olan etkisini "duygular davranışı harekete geçirebilir, bir şeyi öne çıarabilir, tercihleri yönlendirebilir ve öteki dürtüleri güçlendirebilir. Bu yüzden, modaya uyma şeklindeki sosyal dürtü, insanın sahip olduğu şeyleri sergilemeden duyduğu gurur tarafından pekiştirilir" şeklinde ifade etmektedirler. Laverie vd.(1993, s.70) hedonik değerlerin canlılık içeren üç duygu ile bağlantılı olduğunu ifade etmektedir. Bu üç duygu; ilgi-merak, şaşkınlık-sürpriz ve zevk-eğlence duygusudur. Mausbach vd. (2009, s.608), davranışsal yapıların (aktivitelere katılma, sosyal aktivitelerde bulunma) pozitif duygular ile bilişsel yapıların (çaresizlik, kendini suçlama ve olumsuz değerlendirmeler) negatif duygular ile ilişkili olduğunu belirtmişlerdir. Watson vd.(1988) pozitif duygu kategorilerini; "heyecanlı, güçlü, hevesli, gururlu, uyanık, ilhamlı, kararlı, aktif, ilgili ve dikkatli" olmak üzere on mad- 
dede negatif duygu kategorilerini ise; "sıkıntılı, mutsuz, suçlu, ürkmüş, düşmanca, asabi, utanmış, sinirli, tedirgin ve korkmuş" olmak üzere on madde altında incelemişlerdir.

Araştırmalarda özellikle olumsuz duyguların gençlerde yaşlılara göre daha yüksek olduğu saptanmıştır (Mroczek ve Kolarz, 1998, s.1333; Ready vd., 2011, s.784). Olumlu ve olumsuz duygulardaki cinsiyet fark1 incelendiğinde, kızların erkeklere göre daha fazla olumsuz duygu yaşadığı saptanmıştır (Ben-zur, 2003, s.67). Erkek ergenlerin negatif duyguları yönetme yeterliliği, kızların ise pozitif duyguları yönetme yeterliliği daha yüksektir (Caprara, 2016, s.30). Duygusal kararlar çoğunlukla kadınlar tarafından yapılır. Kadınlar tarafından satın alınan moda ürünleri etkileyici bir şekilde yayılmıştır, bu da çoğu kadının satın alımlarını kontrol edemediğini göstermektedir (Vohs ve Faber, 2007, s.125). Kadınların yaklaşık \% 59'u ve erkeklerin \% 48'i plansız satın alma davranışında bulunmaktadır. Bu durum, kadınların plansız satın alma davranışının erkeklerden daha fazla olduğunu göstermektedir. Kadınlar tarafından satın alınan ürünler, kıyafet, kozmetik, aksesuar, mücevher, moda ürünleri ve sosyal statüsünü belirleyebilecek ürünlerdir (KongHee, 2012, s.105). Plansız satın alma; yalnızca bir rahatlık, memnuniyet ve zevk duygusu sağlayarak mutluluğa neden olmaz aynı zamanda pişmanlıkla da sonuçlanabilir. Saleh (2012, s.106) yaptığı araştırmada plansız satın alımın pişmanlığa yol açtı̆̆ını belirtmektedir. Buna karşılık Gardner vd. (1998, s.127) plansız satın almaktan hoşlanan bir kişinin iyi bir duygu, eğlence ve hatta mutluluk yaşayabileceğini belirtmektedir. Aradaki fark, plansız satın alma olumsuz duygular sonucunda da ortaya çıkabilir, çünkü kişinin ruh hali kötüdür ve sonrasında pişmanlık ve yanılgı olabilir. Diğer yandan plansız satın alma olumlu duygulara dayanıyorsa, sonuçta birey mutlu olacaktır (Gardner, 1988; Saleh, 2012).

Silvera vd. (2008), plansız satın alma davranışını olumsuz psikolojik durumlardan bir kaçış olarak ifade etmektedir. Verplanken vd. (2005, s.429) genel olarak plansız satın alma eğiliminin uzun vadeli olumsuz ruh hali ve düşük özgüven ile ilişkili olduğunu öne sürmüşlerdir. Dahas1, Sneath vd. (2009, s.45), zor şartlar altındaki tüketicilerin kendi kendine hediye veya ödül olarak algılanan alımlara eğilimli olduğunu belirtmişlerdir. Bu nedenle, plansız satın alımların stresli olaylarla ilişkili hayal kırıklığını ve depresyonu azaltmak için çabalayan alıcıların ras- 
yonel bir tepkisi olabileceği sonucuna varılmıştır. Tüketicinin satın alım eğilimi, genellikle olumlu bir duygusal değişimin eşlik ettiği inancı ile tetiklenir (Amos vd., 2014, s.86) ve olumsuz durumu azaltmak için yapılır (Sneath vd., 2009, s.45). Ayrıca, araştırmalar materyalist tüketicilerin plansız satın alımlara daha fazla meyilli olduğunu göstermektedir (Badgaiyan ve Verma, 2014, s.538).

Mutluluk ile plansız satın alma davranışı arasındaki ilişkiyi tespit eden çalışmalarda mevcuttur. Daha az mutlu tüketicilerin, plansız satın alma davranışlarına daha yatkın olma ihtimali yüksektir. Bu varsayım, plansız satın almanın olumsuz psikolojik durumdan kaçınmayı sağlayan bir mekanizma olarak da işlev görebileceğini ortaya koyan araştırma sonuçlarıyla da güçlendirilmiştir (Silvera vd., 2008; Verplanken vd., 2005 'ten akt. Šeinauskienė, 2015, s.688). Mutluluk halini sürdürebilmek için maddi yönelimli toplum tüketicileri, kendilerini mutlu edecek ve hayal kırıklığını ve olası bir markalaşma riskinden doğabilecek mutsuzluk halini önlemek için denemelerden kaçınacakları malları satın alacaklardır (Podoshen ve Andrzejewski, 2012, s.319). Mutluluğu en önemli faktör olarak gören tüketiciler marka değiştirmeye eğilimli olmayacaklardır. Son olarak yapılan bazı araştırmalarda, tüketimin artmasına meyilli olan toplum üyelerinin daha az mutlu oldukları ifade edilmektedir (Podoshen vd.,2014, s.271).

\section{Yöntem}

\section{Araştırmanın Ana Kütlesi ve Çalışma Grubu}

Araştırmanın ana kütlesini Sivas ilinde yaşayan kişiler oluşturmaktadır. Çalışma grubunu ise 2018 yılında Sivas ili şehir merkezinde yaşayan 17 yaş ve üzeri 399 kişi oluşturmaktadır. Çalışma grubunun belirlenmesinde kolayda örnekleme yöntemi esas alınmıştır. Veriler, katılımcılarla yüz yüze anket tekniği kullanılarak bizzat araştırmacılar tarafından toplanmıştır. 


\section{Veri Toplama Aracı}

Anket 5'li Likert tipi (1-Kesinlikle Katılmıorum,..., 5-Kesinlikle Katılıyorum) toplam 63 ifadeden oluşmaktadır. Ankette üç farklı ölçek kullanılmıştır. Ankette yer alan "Anlık Duygu Durumu" ifadeleri Kuzucu'nun (2011) çalışmasından, "Mutluluk" ifadeleri Akduman'ın (2015) çalışmasından ve "Plansız Satın Alma" ifadeleri de Özkan'ın (2018) çalışmasından alınmıştır. Ayrıca katılımcıların demografik özelliklerini içeren toplam 6 adet ifade de ankette yer almaktadır.

\section{Araştırmanın Modeli ve Hipotezler}

Son yıllarda ekonomik sebepler ve rasyonellik, tutku ve irrasyonellik ile yer değiştirmiştir. Günümüz toplumu, duygusal bileşene ve seçme ve satın alma özgürlüğüne verilen önemle karakterize edilmektedir. Tüketim, satın alma eyleminde hedonizm arayan tüketici için duygusal açıdan memnuniyet verici bir deneyim üretmenin aracı haline gelmiştir. $\mathrm{Bu}$ durum, tüketimin bir yaşam tarzı haline geldiği gerçeğini desteklemektedir (Bessouh vd., 2017, s.1). Dolayısıyla günümüz tüketicileri anlık duygu durumları ve mutluluğun etkisiyle daha güçlü plansız satın alma davranışı göstermektedir. Buradan yola çıkarak bu araştırmada anlık duygu durumu ve mutluluk bağımsız değişkenler, plansız satın alma davranışı ise bağımlı değişken olarak dikkate alınmış ve aşağıdaki model ortaya çıkmıştır.

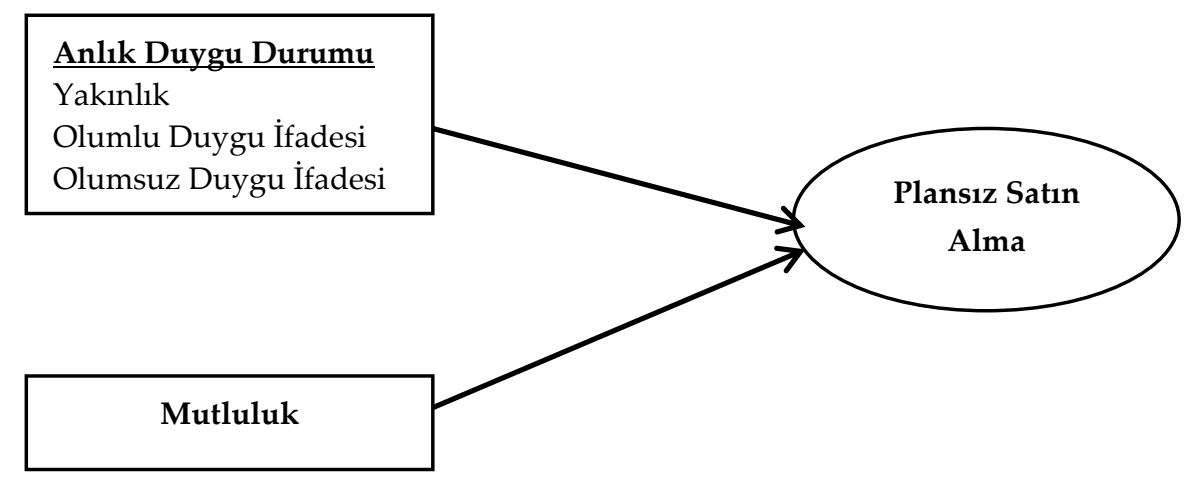

Şekil 1. Araştırma Modeli 
Anlık duygu durumu bağımsız değişkeni kendi içerisinde "Yakınlık", "Olumlu Duygu İfadesi" ve "Olumsuz Duygu İfadesi" şeklinde üç alt değişken olarak alınmıştır. Yine "Mutluluk" değişkeni de diğer bir bağımsız değişkeni ifade etmektedir. Plansız Satın Alma değişkeni ise bağımlı değişkeni ifade etmektedir. Modelde bağımsız değişkenlerden bağımlı değişkenler giden oklar ise regresyon ilişkisini göstermektedir. Modele gore kurulan hipotezler ise aşağıdaki gibidir:

- H1a: Yakınlık cinsiyete göre farklılık göstermektedir.

- H1b: Olumlu Duygu İfadesi cinsiyete göre farklılık göstermektedir.

- H1c: Olumsuz Duygu İfadesi cinsiyete göre farkl1lık göstermektedir.

- H1d: Mutluluk cinsiyete göre farklılık göstermektedir.

- H1e: Plansız Satın Alma cinsiyete göre farklılık göstermektedir.

- H2a: Yakınlık medeni duruma göre farklılık göstermektedir.

- H2b: Olumlu Duygu İfadesi medeni duruma göre farklılık göstermektedir.

- H2c: Olumsuz Duygu İfadesi medeni duruma göre farkl1lık göstermektedir.

- H2d: Mutluluk medeni duruma göre farklılık göstermektedir.

- H3a: Yakınlık yaşa göre farklılık göstermektedir.

- H3b: Olumlu Duygu İfadesi yaşa göre farklılık göstermektedir.

- H3c: Olumsuz Duygu İfadesi yaşa göre farklılık göstermektedir.

- H3d: Mutluluk yaşa göre farklılık göstermektedir.

- H3e: Plansız Satın Alma yaşa göre farklılık göstermektedir.

- H4a: Yakınlık eğitim durumuna göre farklılık göstermektedir.

- H4b: Olumlu Duygu İfadesi eğitim durumuna göre farklılık göstermektedir.

- H4c: Olumsuz Duygu İfadesi eğitim durumuna göre farklılık göstermektedir.

- H4d: Mutluluk eğitim durumuna göre farklılık göstermektedir.

- H4e: Plansız Satın Alma eğitim durumuna göre farklılık göstermektedir.

- H5a: Yakınlık gelire göre farklılık göstermektedir.

- H5b: Olumlu Duygu İfadesi gelire göre farklılık göstermektedir.

- H5c: Olumsuz Duygu İfadesi gelire göre farklılık göstermektedir.

- H5d: Mutluluk gelire göre farklılık göstermektedir.

- H5e: Plansız Satın Alma gelire göre farklılık göstermektedir. 
- H6a: Yakınlık meslek türüne göre farklılık göstermektedir.

- H6b: Olumlu Duygu İfadesi meslek türüne göre farklılık göstermektedir.

- H6c: Olumsuz Duygu İfadesi meslek türüne göre farkl1lık göstermektedir.

- H6d: Mutluluk meslek türüne göre farklılık göstermektedir.

- H6e: Plansız Satın Alma meslek türüne göre farklılık göstermektedir.

- H7: Yakınlık ile Plansız Satın Alma arasında pozitif ve anlamlı bir ilişki vardır.

- H8: Olumlu Duygu İfadesi ile Plansız Satın Alma arasında pozitif ve anlamlı bir ilişki vardır.

- H9: Olumsuz Duygu İfadesi ile Plansız Satın Alma arasında pozitif ve anlamlı bir ilişki vardır.

- H10: Mutluluk ile Plansız Satın Alma arasında pozitif ve anlamlı bir ilişki vardır.

- H11: Yakınlık, Olumlu Duygu İfadesi, Olumsuz Duygu İfadesi ve Mutluluk değişkenleri Plansız Satın Alma davranışını anlamlı ve pozitif bir şekilde etkilemektedir.

\section{Kullanılan Analiz Teknikleri}

Yakınlık, Olumlu Duygu İfadesi, Olumsuz Duygu İfadesi, Mutluluk ve Plansız Satın Alma değişkenlerinin cinsiyet, yaş, gelir durumu, eğitim durumu ve meslek türü gibi bazı demografik faktörler açısından incelenmesinde öncelikle Kolmogorov-Smirnov testi ile normallik sinaması yapılmıştır. Değişkenlerin hepsinin normal dağıldığı $(p>0,05)$ görülmüş ve bu doğrultuda parametrik teknikler olan bağımsız gruplar için $\mathrm{t}$ testi ve tek yönlü varyans analizi (ANOVA) kullanılmıştır.

Ayrica yakınlık, olumlu duygu durumu, olumsuz duygu durumu ve mutluluğun plansız satın alma davranışı üzerinde etkisinin olup olmadığı ise Pearson korelasyon katsayısı ve çoklu doğrusal regresyon analizi ile incelenmiştir.

Çalışmada kullanılan tüm istatistiksel analizler SPSS 22 paket programı ile gerçekleştirilmiştir. 


\section{Bulgular}

\section{Demografik Verilere Ait Bulgular}

Çalışmada katılımcıların demografik özelliklerini gösteren değişkenler ve bunların frekans dağılımları Tablo 1'de görüldüğg̈ gibidir.

Tablo 1. Katılımcıların Demografik Özellikleri

\begin{tabular}{llllll}
\hline Yaş & Frekans & Yüzde & Eğitim Durumu & Frekans & Yüzde \\
\hline 17-22 Yaş & 96 & 24,1 & Okur-yazar & 13 & 3,3 \\
23-28 Yaş & 108 & 27,1 & Orta Öğretim & 43 & 10,8 \\
29-34 Yaş & 54 & 13,5 & Lise & 109 & 27,3 \\
35-40 Yaş & 58 & 14,5 & Ön Lisans & 45 & 11,3 \\
41-46 Yaş & 30 & 7,5 & Üniversite & 169 & 42,4 \\
47 Yaş ve üstü & 53 & 13,3 & Lisansüstü & 20 & 5,0 \\
\hline Toplam & 399 & $\mathbf{1 0 0 , 0}$ & Toplam & $\mathbf{3 9 9}$ & $\mathbf{1 0 0 , 0}$ \\
\hline Meslek Türü & Frekans & Yüzde & Gelir Dağ1lımı & Frekans & Yüzde \\
\hline Memur & 69 & 17,3 & 2000 TL'den az & 117 & 29,3 \\
Ev hanımı & 45 & 11,3 & 2001-3500 TL & 145 & 36,3 \\
İşçi & 48 & 12,0 & 3501-5000 TL & 89 & 22,3 \\
Serbest & 45 & 11,3 & 5001-6500 TL & 28 & 7,0 \\
Mes. Erb & & & & & \\
Öğrenci & 56 & 14,0 & 6501 TL ve üzeri & 20 & 5,0 \\
Esnaf & 30 & 7,5 & Toplam & 399 & $\mathbf{1 0 0 , 0}$ \\
Özel Sektör & 66 & 16,5 & Cinsiyet & Frekans & Yüzde \\
\cline { 3 - 5 } Diğer & 40 & 10,0 & Kadın & 197 & 49,4 \\
\hline Toplam & 399 & $\mathbf{1 0 0 , 0}$ & Erkek & 202 & 50,6 \\
\hline Medeni Hal & Frekans & Yüzde & Toplam & $\mathbf{3 9 9}$ & $\mathbf{1 0 0 , 0}$ \\
\hline Evli & 186 & 46,6 & & & \\
Bekâr & 213 & 53,4 & & & \\
Toplam & $\mathbf{3 9 9}$ & $\mathbf{1 0 0 , 0}$ & & & \\
\hline
\end{tabular}

Tablo 1'e bakıldığında araştırmaya katılanların \%49,4'ü kadın, \%50,6'sı erkeklerden oluşmaktadır. Yaş dağılımına bakıldığında en yüksek katılım \%27,1 ile 23-28 yaş aralığındakilerde; en az katılım ise $\% 7,5$ ile 41-46 yaş aralığındaki gruptadır. Eğitim durumuna göre katılımciların \%42,4'ü Üniversite mezunu, \%27,3'ü Lise mezunu ve 
$\% 10,8$ i ise Ortaöğretim mezunudur. Gelir durumuna göre katılımcların \%29,3'ü 2000 TL ve altında, \%36,3'ü 2001-3500 TL, \%22,3'ü 3501-5000 TL, $\% 7$ 'si 5001-6500TL ve \%5'i ise 6501 TL ve üzeri geliri olan gruptadır. Son olarak meslek türüne göre dağılıma bakıldığında dağılımın birbirine yakın ve dengeli olduğu görülmekte ve en çok katılımın \%17,3 ile memurlarda, en az katılımın ise \%7,5 ile esnaflarda olduğu görülmektedir.

\section{Bă̆ımsız Örneklemler T Testine İlişkin Bulgular}

\section{Cinsiyete Göre Faktörlerin Test Edilmesi}

"Yakınlık", "Olumlu Duygu İfadesi", "Olumsuz Duygu İfadesi", "Mutluluk" ve "Plansız Satın Alma" faktörlerinin cinsiyete göre anlamlı bir farklılık gösterip göstermediği bağımsız örneklemler $t$ testi ile test edilmiştir. Öncelikle faktörlere Levene homojenlik testi uygulanmış ve sonuçlar Tablo 2'deki gibi bulunmuştur. Buna göre varyansların homojen olduğu tespit edilmiştir ( $p>0,05)$.

Tablo 2. Levene Homojenlik Tablosu

\begin{tabular}{|c|c|c|c|c|c|c|}
\hline & \multicolumn{2}{|c|}{ Levene Testi } & \multicolumn{3}{|c|}{ T Testi } \\
\hline & & $\mathbf{F}$ & p & $\mathbf{t}$ & SD & $\mathrm{p}$ \\
\hline \multirow{2}{*}{ Yakınlık } & Varyanslar Eşit & 5,663 & ,058 & 4,161 & 397 & 000 \\
\hline & Varyanslar Eşit Değil & & & 4,170 & 387,876 & 000 \\
\hline \multirow{2}{*}{$\begin{array}{l}\text { Olumlu } \\
\text { Duygu İf. }\end{array}$} & Varyanslar Eşit & 7,256 & ,057 & 4,355 & 397 & 000 \\
\hline & Varyanslar Eşit Değil & & & 4,363 & 391,600 & ,000 \\
\hline \multirow{2}{*}{$\begin{array}{l}\text { Olumsuz } \\
\text { Duygu İf. }\end{array}$} & $\underline{\text { Varyanslar Eşit }}$ & , 250 & 617 & ,285 & 397 & ,775 \\
\hline & Varyanslar Eşit Değil & & & ,286 & 395,970 & ,775 \\
\hline \multirow{2}{*}{ Mutluluk } & Varyanslar Eşit & 1,082 & , 299 & ,557 & 397 & ,578 \\
\hline & Varyanslar Eşit Değil & & &, 558 & 394,354 &, 577 \\
\hline Plansiz & Varyanslar Eşit & ,001 & 969 & 1,301 & 397 & ,194 \\
\hline Satın Alma & Varyanslar Eşit Değil & & & 1,302 & 395,755 & ,194 \\
\hline
\end{tabular}

Varyansların homojenliği varsayımının da sağlanmasıyla birlikte yapılan bağımsız gruplar için $t$ testi sonucunda elde edilen bulgular Tablo 3'deki gibidir. 
Tablo 3. Cinsiyete Göre Faktörlerin Karşılaştırması

\begin{tabular}{|c|c|c|c|c|c|c|}
\hline & Cinsiyet & $\mathbf{N}$ & Ort. & $\begin{array}{l}\text { Std. Sap- } \\
\text { ma }\end{array}$ & $\mathbf{t}$ & p \\
\hline \multirow{2}{*}{ Yakınlık } & Kadın & 197 & 3,5195 & 61079 & \multirow{2}{*}{4,161} & \multirow{2}{*}{,000 } \\
\hline & Erkek & 202 & 3,2384 & ,73127 & & \\
\hline Olumlu & Kadın & 197 & 3,5421 & ,59152 & \multirow[b]{2}{*}{4,355} & \multirow[b]{2}{*}{,000 } \\
\hline $\begin{array}{l}\text { Duygu } \\
\text { İfadesi }\end{array}$ & Erkek & 202 & 3,2634 & 68265 & & \\
\hline Olumsuz & Kadın & 197 & 3,6472 & 70478 & & \\
\hline $\begin{array}{l}\text { Duygu } \\
\text { İfadesi }\end{array}$ & Erkek & 202 & 3,6262 & 76060 & 285 & 775 \\
\hline \multirow{2}{*}{ Mutluluk } & Kadın & 197 & 3,2029 & 31792 & \multirow{2}{*}{, 557} & \multirow{2}{*}{,578 } \\
\hline & Erkek & 202 & 3,1841 & ,35393 & & \\
\hline Plansız & Kadın & 197 & 3,1571 & ,38904 & \multirow{2}{*}{1,301} & \multirow{2}{*}{1,19} \\
\hline Satın Alma & Erkek & 202 & 3,1042 & ,42199 & & \\
\hline
\end{tabular}

Tablo 3'deki sonuçlara göre "Olumsuz Duygu İfadesi", "Mutluluk" ve "Plansız Satın Alma" faktörleri cinsiyete göre anlamlı bir farklılık göstermemektedir(p>0,05) ve H1b, H1d ve H1e hipotezleri reddedilmiştir. "Yakınlık" $(\mathrm{t}=4,161 ; \mathrm{p}(0,000)<0.05)$ ve "Olumlu Duygu İfadesi" $(\mathrm{t}=4,355 ; \mathrm{p}(0,000)<0.05)$ faktörleri ise cinsiyete göre anlamlı bir farklılık göstermektedir. Böylece $\mathrm{H} 1 \mathrm{a}$ ve $\mathrm{H} 1 \mathrm{c}$ hipotezleri kabul edilmiştir. Ortalamalara bakıldığında iki faktörde de kadınların erkeklerden daha yüksek bir ortalamaya sahip olduğu, yakınlık duyma ve olumlu duyguya sahip olma açısından erkeklerden ayrıştığı söylenebilir. Bu durum, kadınların erkeklere göre genel olarak duygularını daha yoğun yaşadığ ile ilgili olabilir. Elde edilen sonuç Ben-zur (2003) tarafından yapılan çalışma ile benzerlik göstermektedir. Benzur (2003, s.67) yaptığı çalışmasinda, kızların erkeklere göre daha fazla olumsuz duygu yaşadığı tespit edilmiştir. Caprara (2016, s.30), ise erkek ergenlerin negatif duyguları yönetme yeterliliğinin, kızların ise pozitif duyguları yönetme yeterliliğinin daha yüksek olduğunu tespit etmiştir.

\section{Medeni Duruma Göre Faktörlerin Test Edilmesi}

Beş faktörün medeni duruma göre karşılaştırılmasında bağımsız gruplar $\mathrm{t}$ testi sonucunda elde edilen bulgular Tablo 4'deki gibidir. 
Tablo 4. Medeni Duruma Göre Faktörlerin Karşılaştırması

\begin{tabular}{|c|c|c|c|c|c|c|}
\hline & $\begin{array}{l}\text { Medeni } \\
\text { Durum }\end{array}$ & $\mathbf{N}$ & Ort. & $\begin{array}{l}\text { Std. } \\
\text { Sapma }\end{array}$ & $\mathbf{t}$ & $\mathbf{p}$ \\
\hline \multirow{2}{*}{ Yakınlık } & Evli & 186 & 3,3862 & 70330 & \multirow{2}{*}{,244 } & \multirow{2}{*}{,807 } \\
\hline & Bekâr & 213 & 3,3693 & ,67623 & & \\
\hline Olumlu & Evli & 186 & 3,3247 & 69089 & \multirow[b]{2}{*}{$-2,189$} & \multirow[b]{2}{*}{,029 } \\
\hline $\begin{array}{l}\text { Duygu } \\
\text { İfadesi }\end{array}$ & Bekâr & 213 & 3,4676 & 61301 & & \\
\hline Olumsuz & Evli & 186 & 3,6438 & 71411 & & \\
\hline $\begin{array}{l}\text { Duygu } \\
\text { İfadesi }\end{array}$ & Bekâr & 213 & 3,6303 & 75023 & ,184 & ,854 \\
\hline \multirow{2}{*}{ Mutluluk } & Evli & 186 & 3,1839 & 34328 & \multirow{2}{*}{,- 522} & \multirow{2}{*}{ 602 } \\
\hline & Bekâr & 213 & 3,2016 & 33075 & & \\
\hline Plans1z & Evli & 186 & 3,1065 & 39553 & \multirow{2}{*}{$-1,097$} & \multirow{2}{*}{ 273 } \\
\hline Satın Alma & Bekâr & 213 & 3,1512 & ,41549 & & \\
\hline
\end{tabular}

Tablo 4'deki sonuçlara göre "Yakınlık", "Olumlu Duygu İfadesi", "Mutluluk" ve "Plansız Satın Alma" faktörleri medeni duruma göre anlamlı bir farklılık göstermemektedir(p>0,05). Dolayısıyla $\mathrm{H} 2 \mathrm{a}, \mathrm{H} 2 \mathrm{c}$, $\mathrm{H} 2 \mathrm{~d}$ ve H2e hipotezleri reddedilmiştir. "Olumsuz Duygu İfadesi" ( $\mathrm{t}=-$ $2,189 ; \mathrm{p}(0,029)<0.05)$ faktörü ise medeni duruma göre anlamlı bir farkl1lık göstermektedir. Böylece $\mathrm{H} 2 \mathrm{~b}$ hipotezi kabul edilmiştir. Ortalamalara bakıldığında bekâr katılımcıların daha fazla olumlu duygu ifadesi gösterdikleri söylenebilir. Bu durumun, evlilerin özel hayatlarında yaşadıkları sorunlardan kaynaklandığının bir göstergesi olabilir. Fakat bu sonucun aksine Usta $(2016$, s.218) tarafından akademisyenler üzerinde yap1lan çalışmada bekârların evlilerden daha çok olumsuz duygu yaşadığ1 tespit edilmiştir.

\section{Tek Yönlü Varyans Analizine İlişkin Bulgular}

\section{Yaş Faktörüne Göre Karşılaştırma}

"Yakınllk", "Olumlu Duygu İfadesi", "Olumsuz Duygu İfadesi", "Mutluluk" ve "Plansız Satın Alma" faktörlerinin katılımcıların yaşlarına göre anlamlı bir farklılık gösterip göstermediği tek yönlü ANOVA ile test 
edilmiştir. Tek yönlü ANOVA testi sonucunda elde edilen bulgular Tablo 5'deki gibidir.

Tablo 5. Yaşa Göre Değişkenlerin ANOVA Testi

\begin{tabular}{|c|c|c|c|c|c|c|}
\hline & $\begin{array}{l}\text { Varyans } \\
\text { Kaynağı }\end{array}$ & $\begin{array}{l}\text { Kareler } \\
\text { Toplamı }\end{array}$ & $\begin{array}{l}\text { Serbestlik } \\
\text { Derecesi }\end{array}$ & $\begin{array}{l}\text { Kareler } \\
\text { Ortalaması }\end{array}$ & F & $\mathrm{p}$ \\
\hline \multirow{3}{*}{ Yakınlık } & Gruplar Arası & 1,192 & 5 & ,238 & & \\
\hline & Gruplar İçi & 187,290 & 393 & ,477 & ,500 & ,776 \\
\hline & Toplam & 188,482 & 398 & & & \\
\hline \multirow{3}{*}{$\begin{array}{l}\text { Olumlu } \\
\text { Duygu Iffadesi }\end{array}$} & Gruplar Arası & 3,959 & 5 & ,792 & & \\
\hline & Gruplar İçi & 166,040 & 393 & ,422 & 1,874 & ,098 \\
\hline & Toplam & 170,000 & 398 & & & \\
\hline \multirow{3}{*}{$\begin{array}{l}\text { Olumsuz } \\
\text { Duygu İfadesi }\end{array}$} & Gruplar Arası & 2,674 & 5 & ,535 & & \\
\hline & Gruplar İçi & 211,007 & 393 & ,537 & ,996 & ,420 \\
\hline & Toplam & 213,681 & 398 & & & \\
\hline \multirow{3}{*}{ Mutluluk } & Gruplar Arası & 672 & 5 & , 134 & & \\
\hline & Gruplar İçi & 44,352 & 393 & 113 & 1,190 & ,313 \\
\hline & Toplam & 45,023 & 398 & & & \\
\hline \multirow{3}{*}{$\begin{array}{l}\text { Plansiz } \\
\text { Satın Alma }\end{array}$} & Gruplar Arası & ,236 & 5 & , 047 & & \\
\hline & Gruplar İçi & 65,502 & 393 & 167 & ,283 & ,922 \\
\hline & Toplam & 65,738 & 398 & & & \\
\hline
\end{tabular}

Tablo 5'e göre "Yakınlık", “Olumlu Duygu İfadesi”, “Olumsuz Duygu İfadesi", "Mutluluk" ve "Plansız Satın Alma" faktörlerinin tamamının katılımcıların yaşlarına göre anlamlı bir farklılık göstermediği sonucuna varılabilir(p>0,05). Buna göre $\mathrm{H} 3 \mathrm{a}, \mathrm{H} 3 \mathrm{~b}, \mathrm{H3c}, \mathrm{H} 3 \mathrm{~d}$ ve H3e hipotezleri reddedilmiştir.

\section{Eğitim Durumuna Göre Karşılaştırma}

Beş faktöründe eğitim durumuna göre karşılaştırılmasında tek yönlü ANOVA testi sonucunda elde edilen bulgular Tablo 6'daki gibidir.

Tablo 6'ya göre "Yakınlık", "Olumlu Duygu İfadesi", "Olumsuz Duygu İfadesi", "Mutluluk" ve "Plansız Satın Alma" faktörlerinin tamamı katılımcıların eğitim durumlarına göre anlamlı bir farklılık göstermemektedir ( $p>0,005)$. Buna göre $\mathrm{H} 4 \mathrm{a}, \mathrm{H} 4 \mathrm{~b}, \mathrm{H} 4 \mathrm{c}, \mathrm{H} 4 \mathrm{~d}$ ve $\mathrm{H} 4 \mathrm{e}$ hipotezleri reddedilmiştir. 
Tablo 6. Eğitim Durumuna Göre Değişkenlerin ANOVA Testi

\begin{tabular}{|c|c|c|c|c|c|c|}
\hline & $\begin{array}{l}\text { Varyans } \\
\text { Kaynağı }\end{array}$ & $\begin{array}{l}\text { Kareler } \\
\text { Toplamı }\end{array}$ & $\begin{array}{c}\text { Serbestlik } \\
\text { Derecesi }\end{array}$ & $\begin{array}{c}\text { Kareler } \\
\text { Ortalaması }\end{array}$ & $\mathbf{F}$ & $\mathrm{p}$ \\
\hline \multirow[t]{3}{*}{ Yakınlık } & Gruplar Arası & 3,278 & 5 & ,656 & & \\
\hline & Gruplar İçi & 185,205 & 393 & ,471 & 1,391 & 227 \\
\hline & Toplam & 188,482 & 398 & & & \\
\hline \multirow{3}{*}{$\begin{array}{l}\text { Olumlu } \\
\text { Duygu İfadesi }\end{array}$} & Gruplar Arası & 5,150 & 5 & 1,030 & & \\
\hline & Gruplar İçi & 164,850 & 393 & ,419 & 2,455 & ,330 \\
\hline & Toplam & 170,000 & 398 & & & \\
\hline \multirow{3}{*}{$\begin{array}{l}\text { Olumsuz } \\
\text { Duygu İfadesi }\end{array}$} & Gruplar Arası & 4,555 & 5 & ,911 & & \\
\hline & Gruplar İçi & 209,126 & 393 & ,532 & 1,712 & 131 \\
\hline & Toplam & 213,681 & 398 & & & \\
\hline \multirow{3}{*}{ Mutluluk } & Gruplar Arası & 683 & 5 & 137 & & \\
\hline & Gruplar İçi & 44,341 & 393 & 113 & 1,210 & ,304 \\
\hline & Toplam & 45,023 & 398 & & & \\
\hline \multirow{3}{*}{$\begin{array}{l}\text { Plansiz } \\
\text { Satın Alma }\end{array}$} & Gruplar Arası & 1,085 & 5 & 217 & & \\
\hline & Gruplar İçi & 64,653 & 393 & , 165 & 1,319 & ,255 \\
\hline & Toplam & 65,738 & 398 & & & \\
\hline
\end{tabular}

\section{Gelir Gruplarına Göre Karşılaştırma}

Beş faktöründe gelir gruplarına göre karşılaştırılmasında tek yönlü ANOVA testi sonucunda elde edilen bulgular Tablo 7'deki gibidir.

Tablo 7. Gelir Gruplarına Göre Değişkenlerin ANOVA Testi

\begin{tabular}{|c|c|c|c|c|c|c|}
\hline & $\begin{array}{l}\text { Varyans } \\
\text { Kaynağ1 }\end{array}$ & $\begin{array}{l}\text { Kareler } \\
\text { Toplamı }\end{array}$ & $\begin{array}{c}\text { Serbestlik } \\
\text { Derecesi }\end{array}$ & $\begin{array}{c}\text { Kareler } \\
\text { Ortalaması }\end{array}$ & $\mathbf{F}$ & $\mathrm{p}$ \\
\hline \multirow{3}{*}{ Yakınlık } & Gruplar Arası & 1,338 & 4 & ,335 & & \\
\hline & Gruplar İçi & 187,144 & 394 & ,475 & 704 & ,589 \\
\hline & Toplam & 188,482 & 398 & & & \\
\hline \multirow{3}{*}{$\begin{array}{l}\text { Olumlu } \\
\text { Duygu İfadesi }\end{array}$} & Gruplar Arası & 1,183 & 4 & ,296 & & \\
\hline & Gruplar İçi & 168,817 & 394 & ,428 & 690 & ,599 \\
\hline & Toplam & 170,000 & 398 & & & \\
\hline \multirow{3}{*}{$\begin{array}{l}\text { Olumsuz Duygu } \\
\text { İfadesi }\end{array}$} & Gruplar Arası & 1,356 & 4 & ,339 & & \\
\hline & Gruplar İçi & 212,325 & 394 &, 539 & 629 & 642 \\
\hline & Toplam & 213,681 & 398 & & & \\
\hline \multirow{3}{*}{ Mutluluk } & Gruplar Arası & ,314 & 4 & ,079 & & \\
\hline & Gruplar İçi & 44,709 & 394 & 113 & 692 & ,598 \\
\hline & Toplam & 45,023 & 398 & & & \\
\hline \multirow{3}{*}{$\begin{array}{l}\text { Plansız } \\
\text { Satın Alma }\end{array}$} & Gruplar Arası & 1,228 & 4 & ,307 & & \\
\hline & Gruplar İçi & 64,510 & 394 & ,164 & 1,876 & ,114 \\
\hline & Toplam & 65,738 & 398 & & & \\
\hline
\end{tabular}


Tablo 7'ye göre faktörlerinin tamamı katılımcıların gelir durumlarına göre anlamlı bir farklılık göstermemektedir $(\mathrm{p}>0,005)$. Buna göre $\mathrm{H} 5 \mathrm{a}$, $\mathrm{H} 5 \mathrm{~b}, \mathrm{H} 5 \mathrm{c}, \mathrm{H} 5 \mathrm{~d}$ ve H5e hipotezleri reddedilmiştir.

\section{Meslek Türlerine Göre Karşılaştırma}

Beş faktöründe meslek türlerine göre karşılaştırılmasında tek yönlü ANOVA testi sonucunda elde edilen bulgular Tablo 8'deki gibidir.

Tablo 8. Meslek Türlerine Göre Değişkenlerin ANOVA Testi

\begin{tabular}{|c|c|c|c|c|c|c|}
\hline & $\begin{array}{l}\text { Varyans } \\
\text { Kaynağı }\end{array}$ & $\begin{array}{l}\text { Kareler } \\
\text { Toplamı }\end{array}$ & $\begin{array}{c}\text { Serbestlik } \\
\text { Derecesi }\end{array}$ & $\begin{array}{c}\text { Kareler } \\
\text { Ortalaması }\end{array}$ & $\mathbf{F}$ & $\mathbf{p}$ \\
\hline \multirow{3}{*}{ Yakınlık } & Gruplar Arası & 2,300 & 7 & ,329 & \multirow{3}{*}{ 690 } & \multirow{3}{*}{ 681 } \\
\hline & Gruplar İçi & 186,183 & 391 & ,476 & & \\
\hline & Toplam & 188,482 & 398 & & & \\
\hline \multirow{3}{*}{$\begin{array}{l}\text { Olumlu } \\
\text { Duygu Ifa- } \\
\text { desi }\end{array}$} & Gruplar Arası & 2,834 & 7 & ,405 & \multirow{3}{*}{ 947 } & \multirow{3}{*}{,470 } \\
\hline & Gruplar İçi & 167,165 & 391 & ,428 & & \\
\hline & Toplam & 170,000 & 398 & & & \\
\hline Olumsuz & Gruplar Arası & 4,522 & 7 & ,646 & \multirow{3}{*}{1,208} & \multirow{3}{*}{ 297 } \\
\hline \multirow{2}{*}{$\begin{array}{l}\text { Duygu İfa- } \\
\text { desi }\end{array}$} & Gruplar İçi & 209,159 & 391 & ,535 & & \\
\hline & Toplam & 213,681 & 398 & & & \\
\hline \multirow{3}{*}{ Mutluluk } & Gruplar Arası & 484 & 7 & ,069 & \multirow{3}{*}{ 607 } & \multirow{3}{*}{,750 } \\
\hline & Gruplar İçi & 44,539 & 391 & 114 & & \\
\hline & Toplam & 45,023 & 398 & & & \\
\hline \multirow{3}{*}{$\begin{array}{l}\text { Plansız } \\
\text { Satın Alma }\end{array}$} & Gruplar Aras1 & 1,457 & 7 & 208 & \multirow{3}{*}{1,266} & \multirow{3}{*}{,266 } \\
\hline & Gruplar İçi & 64,281 & 391 & ,164 & & \\
\hline & Toplam & 65,738 & 398 & & & \\
\hline
\end{tabular}

Tablo 8'e göre faktörlerinin tamamı katılımcıların gelir durumlarına göre anlamlı bir farklılık göstermemektedir ( $>>0,005)$. Buna göre H6a, H6b, H6c, H6d ve H6e hipotezleri reddedilmiştir.

\section{Korelasyon Analizine İlişkin Bulgular}

"Yakınlık", "Olumlu Duygu İfadesi", "Olumsuz Duygu İfadesi", "Mutluluk" ve "Plansız Satın Alma" değişkenlerinin arasındaki ilişkinin yö- 
nünü ve gücünü tespit edebilmek amaciyla Pearson (r) Korelasyon analizi uygulanmıştır. Korelasyon analizi sonuçları Tablo 9'daki gibidir.

Tablo 9. Faktörler Arasındaki Korelasyon İlişkileri

\begin{tabular}{|c|c|c|c|c|c|c|}
\hline & & & Plansiz & & & Olumsuz \\
\hline & & Mutluluk & $\begin{array}{l}\text { Satin } \\
\text { Alma }\end{array}$ & Yakınlık & $\begin{array}{c}\text { Duygu } \\
\text { Durumu }\end{array}$ & $\begin{array}{c}\text { Duygu } \\
\text { Durumu }\end{array}$ \\
\hline Mutluluk & $f$ & 1 &, $363^{* *}$ & $468^{* *}$ &, $437^{* *}$ & $206^{* *}$ \\
\hline & t & & ,000 & ,000 & ,000 & ,000 \\
\hline & $\mathrm{n}$ & 399 & 399 & 399 & 399 & 399 \\
\hline Plansız & $f$ & $363^{* *}$ & 1 & $286^{* *}$ & $262^{* *}$ &, $182^{* *}$ \\
\hline Satın Alma & $\mathrm{p}$ &, 000 & & ,000 & ,000 & ,000 \\
\hline & $\mathrm{n}$ & 399 & 399 & 399 & 399 & 399 \\
\hline Yakınlık & $f$ & $468^{* *}$ & $286^{* *}$ & 1 & $480^{* *}$ & $226^{* *}$ \\
\hline & $\mathrm{p}$ &, 000 & ,000 & &, 000 &, 000 \\
\hline & $\mathrm{n}$ & 399 & 399 & 399 & 399 & 399 \\
\hline Olumlu Duygu & $f$ & $437^{* *}$ & $262^{* *}$ & $480^{* *}$ & 1 & $197^{* *}$ \\
\hline Durumu & $\mathrm{p}$ & ,000 & ,000 & ,000 & & ,000 \\
\hline & $\mathrm{n}$ & 399 & 399 & 399 & 399 & 399 \\
\hline Olumsuz Duygu & $f$ & $206^{* *}$ & $182^{* *}$ & $226^{* *}$ & $197^{* *}$ & 1 \\
\hline Durumu & $\mathrm{p}$ & ,000 &, 000 &, 000 &, 000 & \\
\hline & $\mathrm{n}$ & 399 & 399 & 399 & 399 & 399 \\
\hline
\end{tabular}

Tablo 9'a göre "Yakınlık" ile "Plansız Satın Alma" arasında pozitif yönde ve düşük düzeyde anlamlı bir ilişki vardır $(\rho=0,286 ; \mathrm{p}<0,05)$ ve $\mathrm{H7}$ hipotezi kabul edilmiştir. "Olumlu Duygu İfadesi" ile "Plansız Satın Alma" arasında pozitif yönde ve düşük düzeyde anlamlı bir ilişki vardir $(\rho=0,262 ; \mathrm{p}<0,05)$ ve H8 hipotezi kabul edilmiştir. "Olumsuz Duygu İfadesi" ile "Plansız Satın Alma" arasında pozitif yönde ve düşük düzeyde anlamlı bir ilişki vardır $(\rho=0,182 ; \mathrm{p}<0,05)$ ve H9 hipotezi kabul edilmiştir. "Mutluluk" ile "Plansız Satın Alma" arasında pozitif yönde ve orta düzeyde anlamlı bir ilişki vardır $(\rho=0,363 ; \mathrm{p}<0,05)$ ve H10 hipotezi kabul edilmiştir.

Beş değişken arasında kurulan toplam dört adet korelasyon ilişkisinin tamaminda değişkenlerin birbirleriyle düşük/orta düzeyde ilişki içinde oldukları sonucuna ulaşılmıştır. Değişkenler arasında ilişkinin gücü ve 
yönü belirlendikten sonra bağımsız değişkenlerin bağımlı değişkeni etkileme durumu için regresyon analizleri gerçekleştirilmiştir.

\section{Regresyon Analizine İlişkin Bulgular}

"Yakınlık", “Olumlu Duygu İfadesi", "Olumsuz Duygu İfadesi" ve "Mutluluk" değişkenlerinin "Plansız Satın Alma" değişkenini etkileme durumunu tespit edebilmek amaciyla Çoklu Doğrusal Regresyon Analizi kullanılmıştır.

"Yakınlık", "Olumlu Duygu İfadesi", "Olumsuz Duygu İfadesi” ve "Mutluluk" değişkenlerinin "Plansız Satın Alma" değişkenini etkileme durumu test edilmiştir. Buna göre sonuçlar Tablo 10'daki gibidir.

Tablo 10. Plansiz Satın Almanın Yakınlık, Olumlu Duygu Ifadesi, Olumsuz Duygu Ífadesi ve Mutluluktan Etkilenme Durumu

\begin{tabular}{|c|c|c|c|c|c|c|c|}
\hline $\begin{array}{l}\text { Bağımlı } \\
\text { Değişken }\end{array}$ & $\begin{array}{l}\text { Bağımsız } \\
\text { Değişken }\end{array}$ & $\beta$ & $\mathbf{t}$ & p & F & $\begin{array}{c}\text { Model } \\
(\mathrm{p})\end{array}$ & $\mathbf{R}^{2}$ \\
\hline \multirow{6}{*}{$\begin{array}{l}\text { Plansız } \\
\text { Satın } \\
\text { Alma }\end{array}$} & Sabit & 1,566 & 8,303 & ,000 & \multirow{6}{*}{19,023} & \multirow{6}{*}{,000 } & \multirow{6}{*}{, 162 } \\
\hline & Yakınlık & ,062 & 1,876 & ,000 & & & \\
\hline & Olumlu Duygu & ,050 & 1,473 & 142 & & & \\
\hline & İfadesi & & & & & & \\
\hline & $\begin{array}{l}\text { Olumsuz Duy- } \\
\text { gu İfadesi }\end{array}$ & ,049 & 1,856 & ,064 & & & \\
\hline & Mutluluk & 315, & 4,780 & ,000 & & & \\
\hline
\end{tabular}

Tablo 10'a göre Plansız Satın Almanın "Yakınlık", "Olumlu Duygu İfadesi" ve "Olumsuz Duygu İfadesi" ve "Mutluluk" değişkenlerinden etkilenme durumunu test etmek için yapılan regresyon modeli istatistiksel olarak anlamlıdır ( $F=19,023 ; p=0,000<0,05)$. Bu modele göre "Yakınlık", “Olumlu Duygu İfadesi", “Olumsuz Duygu İfadesi” ve "Mutluluk" Plansız Satın Almayı olumlu yönde etkilemektedir ve buna göre H11 hipotezi kabul edilmiştir. Başka bir ifadeyle "Yakınlı", "Olumlu Duygu İfadesi", "Olumsuz Duygu İfadesi" ve "Mutluluk" değişkenleri, Plansız Satın Almayı yaklaşık olarak \%17 oranında açılamaktadır ( ${ }^{2}$ $=0,162)$. Bu sonuca göre katılımcıların plansız satın alma davranışlarının yaklaşık \%17'lik kısmının anlık duygu durumu alt değişkenlerinden ve mutluluktan kaynaklanmakta olduğu söylenebilir. 


\section{Sonuç ve Öneriler}

Araştırmada anlık duygu durumu ve mutluluk değişkenlerinin bireylerin plansız satın alma davranışı üzerindeki etkisi incelenmeye çalışılmıştır. Bu bağlamda ilk olarak anlık duygu durumu ölçeğinin alt değişkenleri olan yakınlık, olumlu duygu ifadesi ve olumsuz duygu ifadesi ile mutluluk ve plansız satın alma değişkenleri katılımcıların yaş, cinsiyet, medeni durum, eğitim durumu ve gelir seviyelerine göre bağımsız örneklemler $\mathrm{t}$ testi ve tek yönlü varyans analizine tabi tutulmuştur. Buna göre bağımsız örneklemler $t$ testi sonucunda yakınlık ve olumlu duygu ifadesi değişkenlerinin cinsiyete göre anlamlı bir farklılık gösterdiği ve kadınların erkeklere göre daha yüksek bir ortalamaya sahip olduğu; diğer değişkenlerin ise anlamlı bir farklılık göstermediği sonucuna ulaşılmıştır. Yine medeni duruma göre yapılan test sonucunda olumlu duygu ifadesi hariç diğer değişkenlerin anlamlı bir farklılık göstermediği; yaş, eğitim durumu, gelir seviyesi ve meslek türlerine göre ise tüm değişkenlerin anlamlı bir farklılık göstermediği görülmüştür.

Çalışmada daha sonra bağımsız değişkenler ile bağımlı değişkenler arasındaki ilişkinin yönünü ve gücünü tespit etmek amacıyla Pearson korelasyon katsayısına bakılmıştır. Buna göre bağımsız değişkenlerin bağımlı değişken ile düşük/orta düzeyde pozitif ve anlamlı bir ilişki içinde oldukları tespit edilmiştir. Değişkenler arasındaki ilişkinin yönü ve gücü belirlendikten sonra bağımsız değişkenlerin bağımlı değişkenleri etkileme durumu incelenmiştir. Bu bağlamda yakınlık, olumlu duygu ifadesi, olumsuz duygu ifadesi ve mutluluk bağımsız değişkenlerinin plansız satın alma bağımlı değişkeni üzerindeki etkisi çoklu doğrusal regresyon analizi ile incelenmiş ve yakınlık, olumlu duygu ifadesi, olumsuz duygu ifadesi ve mutluluk bağımsız değişkenlerinin plansız satın almayı yaklaşık olarak \%17 oranında açıkladığı bulunmuştur.

Araştırmanın sadece Sivas ili şehir merkezinde yapılması, zaman ve maliyet gibi zorluklardan dolayı örneklem sayısının fazla olmaması ve kullanılan istatistiksel teknikler bu çalışmanın kısıtlarını oluşturmaktadır. Daha geniş kapsamlı, daha büyük sayıda örneklem gruplarıyla daha farklı istatistiksel teknikler kullanılması halinde bu konuda daha iyi sonuçlara ulaşılması mümkün olacaktır. 


\title{
EXTENDED ABSTRACT Instant Emotion Status and the Effect of Happiness on Unplanned Purchase
}

\author{
* \\ İbrahim Yemez - Şükran Karaca \\ Cumhuriyet University
}

In recent years, economic reasons and rationality have been replaced by passion and irrationality. Today's society is characterized by the importance given to the emotional component and the freedom to choose and buy. Consumption has become a means of producing an emotionally satisfying experience for the consumer looking for hedonism in the act of buying. This situation supports the fact that consumption has become a lifestyle (Bessouh et al., 2017, p.1). Therefore, today's consumers show stronger unplanned buying behavior with the effect of instant feelings and happiness. In this context, the aim of this study is to examine the effect of momentary mood and happiness variables on the unplanned buying behavior of individuals.

The population of the study is composed of people living in Sivas. The study group consisted of 399 people aged 17 years and older living in the city center of Sivas in 2018. In order to determine the study group, sampling method was used as easy. The data were collected by the researchers themselves using face-to-face survey technique Questionnaire 5-Likert type (1-Strongly Disagree, .....,5-Strongly Agree) consists of a total of 63 statements. Three different scales were used in the questionnaire. The Momentum Emotional Status statements in the survey were taken from the work of Kuzucu (2011), the statements of Happiness statements (2015) and the unplanned purchase statements from Özkan's (2018) study. In addition, a total of 6 statements including demographic characteristics of the participants were included in the survey.

According to the results obtained; negative emotion expression, happiness and unplanned purchasing factors do not show a significant difference according to gender. Affinity and positive emotion expression factors show a significant difference according to gender. In terms of mari- 
tal status, affinity, positive emotion expression, happiness and unplanned purchasing factors do not show a significant difference, whereas negative emotion expression factor shows a significant difference according to marital status. Affinity, negative emotion expression, positive emotion expression, happiness and unplanned purchase do not show a significant difference according to age, education, income and occupation types. According to the results of Pearson (r) Correlation analysis conducted in order to determine the direction and strength of the relationship between affinity, positive emotion expression, negative emotion expression, happiness and unplanned purchase; a positive and low positive relationship between affinity and unplanned procurement, between positive emotion expression and unplanned purchasing, positively and at a low level, between negative emotion expression and unplanned purchase, there was a positive and moderate significant relationship between happiness and unplanned purchase. The regression model was used to test the effect of unplanned purchasing on affinity, positive emotion expression and negative emotion expression and happiness variables $(\mathrm{F}=19,023 ; \mathrm{p}=0,000<0,05)$. According to this model, affinity, positive emotion expression, negative emotion expression and happiness affect the unplanned purchase.

In this study, it was tried to examine the effect of momentary mooand happiness variables on the unplanned buying behavior of individuals. In this context, firstly, the sub-variables of instant mood scale, affinity, positive emotion expression and negative emotion expression, and happiness and unplanned purchasing variables were analyzed by independent samples $t$ test and one-way analysis of variance according to age, gender, marital status, education level and income levels. have been subjected. According to the results of independent samples $t$ test, there is a significant difference between the variables of intimacy and positive emotion expression according to gender and women have a higher average than men; the other variables were not significantly different.According to the marital status test, there was no significant difference between the variables except the positive emotion expression. According to age, education level, income level and occupation types, all variables did not show a significant difference. 
In the study, Pearson correlation coefficient was examined in order to determine the direction and strength of the relationship between independent variables and dependent variables. According to this, it was determined that independent variables had a low / medium positive and significant relationship with dependent variable. After determining the direction and strength of the relationship between the variables, the effect of independent variables on the dependent variables was examined. In this context, the effect of affinity, positive emotion expression, negative emotion expression and happiness independent variables on the unplanned purchase dependent variable was investigated by multiple linear regression analysis, and the affinity, positive emotion expression, negative emotion expression and happiness independent variables were approximately $17 \%$ it was found.

The research is not limited to the number of samples due to the difficulties in the city center of Sivas, time and cost, and the statistical techniques used constitute the constraints of this study. A broader range of sample groups will provide better results with different statistical techniques.

\section{Kaynakça / References}

Amos, C., Holmes, G. R., ve Keneson, W. C. (2014). A meta-analysis of consumer impulsebuying. Journal Of Retailing And Consumer Services, 21, 86-97.

Argyle, M., Martin, M., ve Crossland, J. (1989). Happiness As A Function Of Personality And Social Encounters. In J.P. Forgas, J.M. Innes (Eds.), Recent advances in social psychology: An international perspective (189- 203). Amsterdam: North Holland, Elsevier Science.

Badgaiyan, A. J. ve Verma, A. (2014). Intrinsic factors affecting impulsive buying behaviour-evidence from India. Journal Of Retailing And Consumer Services, 21, 537-549.

Ben-Zur H.(2003). Happy Adolescents: The link between subjective wellbeing, internal resources and parental factors. J. Youth Adolesc, 32, 67-79. 
Bessouh, N. ve Belkhir, D. (2018). The effect of mood on impulse buying behavior: Case of Algerian buyers, Austin J. Bus Adm Manage, 2(1), 1023.

Bessouh, N., Saidi, T. ve Belarbi, A.(2017). Women and the purchasing decision, British Journal Of Marketing Studies, 5, 1-12.

Caprara, G., Steca, P., Gerbino, M., Paciello, M. ve Vecchio, G.(2006). Looking for adolescents' well-being: Self-efficacy beliefs as determinants of positive thinking and happiness. Epidemiol Psychiatr Soc, 15, 30-43.

Cropanzano, R., Weiss, H. M., Hale, J. M. S. ve Reb, J. (2003). The structure of affect: Reconsidering the relationship between negative and positive affectivity, Journal Of Management, 29(6), 831-857.

Dittmar, H. ve Drury, J. (2000). Self-1magine-is it in the bag? A qualitative comparison between 'ordinary 'and 'excessive' consumers, Journal Of Economic Psychology, 21, 109-142.

Doğan, T. ve Sapmaz, F. (2012). Mutluluk ve yaşam doyumunun yordayıcısı olarak iyimserlik. Mersin Üniversitesi Ĕ̆itim Fakültesi Dergisi, 8 (3), 391-400.

Doğan, Y. ve Özdevecioğlu M. (2009). Pozitif ve negatif duygusallığın çalışanların performansları üzerindeki etkisi, Sü libf Sosyal Ve Ekonomik Araştırmalar Dergisi,9(18), 165-190.

Fernandez-Abascal, E. G. and Diaz, D. M. (2013). Affective induction and creative thiking, Creativity Research Journal, 25(2), 213-221.

Filser, M. (1996), Vers une consommation plus affective, Reoue Française De Gestion,110, 90-99.

Gardner, M.P ve Rook, D.W (1988). Effects of impulse purchase on consumers:Affectivestates, Advances in Consumer Research, 15, 127130.

Handayani, W., Anshori, M., Usman, I. veMudjanarko, S. W. (2018). Why are you happy with impulse buying?: Evidence from Indonesia. Management Science Letters, 8(5), 283-292.

Kong-Hee, K. (2012). Emotion and strategic decision-making behavior: Developing a theoretical model, International Journal Of Business And Socialscience, 3(1), 105-113. 
Laveri, D. A., Kleine, R. E. ve Kleine, S. S. (1993). Linking emotions and values in consumption experiences: An exploratory study, Advances In Consumer Research, 20, 70-75.

Lichtle, M.C. ve Plichon, V. (2005). La diversite des etats affectifs sur le point de vente, Decision Marketing, 39, 33-42.

Mausbach, B.T., Roepke, S.K., Depp, C.A., Patterson, T.L. ve Grant, I.(2009). Specificity of cognitive and behavioral variables to positive and negative affect. Behav Res Ther, 47,608-615.

Mroczek, D.K., ve Kolarz, C. M. (1998). The effect of age on positive and negative affect: A developmental perspective on happiness. J Pers Socpsychol, 75, 1333-1349.

O'shaughnessy, J., and Jackson, O. N. (2002). Marketing, the consumer Societyandhedonism. Europeanjournal of Marketing, 36(5-6), 524547.

Piron, F. (1993). A comparison of emotional reactions experienced by planned, unplanned and impulse purchasers, in $\mathrm{Na}$-Advances İn Consumer Research, 20, Eds. Leigh Mcalister And Michael L. Rothschild, Provo, Ut: Association For Consumer Research, 341-344.

Podoshen, J. S. ve Andrzejewski, S. A. (2012). An examination of the relationships between materialism, conspicuous consumption, impulse buying, and brand loyalty. Journal of Marketing Theory And Practice, 20, 319-334.

Podoshen, J. S., Andrzejewski, S. A. ve Hunt, J. (2014). Materialism, conspicuous consumption and American hip-hop subculture. Journal of International Consumer Marketing, 26(4), 271-283.

Ready, R.E, Vaidya, J.G, Watson, D., Latzman, R.D., Koffel E.A. ve Clar, L.A.(2011). Age-group differences in facets of positive and negative affect. Aging Ment Health, 15,784-795.

Rook, D. W. ve Stephen J. H. (1985). Consuming impulses, in advances in consumer research, 12, Eds. Morris B. Holbrook And Elizabeth C. Hirschman, Provo, Ut: Association For Consumer Research, 2327.

Rook, D. W. (1987). The buying impulse. Journal Of Consumer Research, 14, 189-199. 
Özkan, S. (2018). Y kuşağının kozmetik ürünlerine karşı plansız satın alma davranışları üzerine bir inceleme. Yayınlanmamış Yüksek Lisans Tezi, Bahçeşehir Üniversitesi Sosyal Bilimler Enstitüsü,İstanbul.

Saleh, M. A. E. H. (2012). An investigation of the relationship between unplanned buying and post purchase regret. International Journal of Marketing Studies, 4(4), 106-120.

Seinauskiene, B., Mascinskiene, J. ve Jucaityte, I. (2015). The relationship of happiness, impusel buying and brand loyalty. Social And Behavioral Sciences, 213, 687-693.

Sheth, J. N. ve Parvatiyar, A. (1995). Thee volution of relationship marketing. International Business Review, 4, 397-418.

Silvera, D. H., Lavack, A. M. ve Kropp, F. (2008). Impulse buying: The role of affect, social influence, and subjective well being. Journal Of Consumer Marketing, 25(1),23-33.

Sneath, J. Z., Lacey, R., ve Kennett-Hansel, P. A.(2009). Coping with a natural disaster: losses, emotions, and impulsive and compulsive buying. Marketing Letters, 20(1), 45-60.

Usta, I. (2006). Liderlik davranışının çalışanlarm öznel iyi oluşları ve işe yabancılaşmaya etkisi: Bir alan araştırması. Yayınlanmamış Doktora Tezi, Trakya Üniversitesi Sosyal Bilimler Enstitüsü, Edirne.

Verplanken, B. ve Herabadi, A. G. (2001). Individual differences impulse buying tendency: Feeling and no thinking. European Journal of Personality, 15, 71-83.

Verplanken, B., Herabadi, A. G., Perry, J. A. ve Silvera, D. H. (2005). Consumer style and health: The role of impulsive buying in unhealthy eating. Psychology\&Health, 20, 429-441.

Vohs, K. ve Ronald, F. R. (2003). Self-regulation and impulsive spending patterns. in Na-Advances in Consumer Research, 30, 125-126.

Watson, D., Clark, L.A. ve Tellegen, A. (1988). Development and validation of brief measure of positive and negative affect: The Panas Scales. Journal of Personality and Social Psychology, 54(6), 1063-1070.

Wilson, W. R. (1967). Correlates of avowed happiness. Psychological Bulletin, 67 (4), 294-306. 


\section{Kaynakça Bilgisi / Citation Information}

Yemez, İ. ve Karaca, Ş. (2019). Anlık duygu durumu ve mutluluğun plansız satın almaya etkisi. OPUS-Uluslararası Toplum Araştırmaları Dergisi, 11(18), 1167-1193. DOI: 10.26466/opus.536345 